\title{
Leadership in Malaysian Paddy Farming
}

\author{
WisamYako Aziz Masso
}

\author{
Norsida Man
}

Department of Agriculture Technology, Faculty of Agriculture, Universiti Putra malaysia (UPM), 43400 Serdang Selangor, Malaysia; Wisam.yako@yahoo.com Norupi45@yahoo.com

\section{Doi:10.5901/ajis.2016.v5n1p257}

\section{Abstract}

\begin{abstract}
Agriculture has a vital role in our livelihood and economic development unlike any other economic activity. Malaysia's leading agricultural yields are in rice, fruit and vegetables. The growing of rice takes up the biggest area, comprising 670,000 ha in 2010 (Dorward, Poole et al. 2003). There are 0.3 million paddy farmers in Malaysia, 40\% of which are full-time, and 65\% of total paddy farms are below one hectare in area(Alam, Siwar et al. 2010). In nascent economies like Malaysia, rural people have relied on extension workers for technical advice and knowledge. The success of extension programs is decided to a great extent by the ability of extension workers, their qualifications and competency, since the whole extension process is reliant on their passing of new ideas and technical advice to the rural people(Idris, Hamzah et al. 2010). In the area of agricultural extension, leadership has crucial longterm importance as it deals with educating groups of farmers in the community .(Khalil 2008) Local leaders are able, in an informal manner, to shape the behavior and attitudes of others towards what is desirable, and the leadership in rural areas has a paramount function in the agricultural extension program .(Rogers 2010).
\end{abstract}

Keywords: leadership, paddy farming ,agriculture extension.

\section{Introduction}

\subsection{Agriculture in Malaysia}

The agricultural sector has had a marked progress during the Eight Malaysia Plan (8thMP). In order to continue this positive development, the Malaysian government had declared the allocation of RM6 billion for agriculture in the 2010 budget. One specific sector that can benefit from this policy is the paddy industry (Shaffril, Asmuni et al. 2010).

Agriculture has a central function in the economy of the least developed countries (LDCs), both in terms of size as well as an element of the development scheme. It represents a large portion of gross domestic product (GDP) (ranging from 30 to 60 percent in about two thirds of them), occupies a significant section of the labour force (ranging from 40 percent to as much as 90 percent in most cases), comprises a major source of hard currency (from 25 percent to as much as 95 percent in three quarters of the countries), provides the majority of basic food and affords subsistence and other income to more than half of the LDCs' population(Nagel 1997).

Agriculture has become the Malaysian economy's third biggest contributor of growth. "During the Ninth Plan period, the agriculture sector will be revitalised to become the third engine of growth. The emphasis will be on new agriculture which will involve large scale commercial farming and the wider application of modern technology"(Austin and Baharuddin 2012).

Agriculture is one of the central ingredients for growth in Malaysia. In the Eight Malaysia Plan and the Ninth Malaysian Plan, the agriculture sector has achieved significant progress. Furthermore, agriculture is planned to be the third highest revenue source for the country during the Ninth Malaysia Plan (Hassan, Shaffril et al. 2010).

\subsection{Paddy Farming Sector in Malaysia}

Paddy farming stands for the cultivation of rice in irrigated low lands. Rice cultivation in Malaysia is seen as the origin of rice farming all around Asia (Man 2009).It is one of the main pillars of the economy of Malaysia along with Palm oil and rubber. This is largely due to the popularity of rice as a daily staple food in Malaysian society(Yin, Ismail et al. 2012).

Malaysia's agricultural industry can be divided into three areas which are food, miscellaneous group and agroindustrial. Paddy farming is one of the most important crops under the subsector of food in Malaysia(Firdaus, Latiff et al. 
2012).

After the green revolution, the paddy industry has been revamped and yields have markedly improved. In 1965, the idea of integrated agriculture development project was put forth with the establishment of the first granary area in Northern Peninsular Malaysia. Today, in order to guarantee sufficient rice production, the government has set up eight grain storage areas in Malaysia.(Roslan, Abdullah et al. 2012).

Singh et al. (1996) reported that yields of rice in Malaysia were between 3-5 tons for every hectare, with potential yield being 7.2 tons. Pio Lopez (2007) claims that rice cultivation in Malaysia is set to end because of the projected decrease in farmed land, static production, increasing costs and diminishing returns. Jayawardane (1996) noted that $90 \%$ of the total paddy yield is needed to cover the cost of labor, energy and fertilizers, with about half going to labor.

Rice production in Malaysia often involves traditional farming as practised by rural inhabitants. The work force is limited in skill and expertise. Poverty is the norm within this sector and government intervention is often needed to keep these farmers afloat (Man 2009).

There are 0.3 million paddy farmers in Malaysia, of which only $40 \%$ are fulltime farmers. Sixty five percent of total paddy farms are below one hectare in size. The current record shows a negative trend of land usage for paddy production. There is a total 426,260 ha paddy planted area, and average yield is 3.5 ton per hectare (Rosegrant, Msangi et al. 2008).

Both government and the private sector have been active in expanding total existing paddy farm land. The paddy improvement zones in Malaysia, for example in Kedah, Selangor, Perak and Sarawak, have to meet the standards of the agriculture extension officer (AEO) so that their paddy range is significantly improved. It is imperative that the paddy estate is developed through new plans and techniques in order for it to become a source of increased revenue for the Malaysian treasury. This makes the contribution of the Ministry of Agriculture and Agro-Based Industry vital for future improvements within the sector(Ali, Altarawneh et al. 2012).

\subsection{Agricultural Extension in Malaysia}

The history of extension services dates back 100 years when it was first utilized to aid some farmers who were ignorant of aspects required to increase agricultural production (Lakai, 2010).

Agricultural extension is the entire set of organizations that support and mentor people engaged in agricultural production to overcome challenges and to get information, skills, and technologies to improve their living standards and well-being (Jadalla, Bakar et al. 2013).

In developing economies such as Malaysia, rural people have relied on extension workers for technical advice and expertise. The success of extension schemes is tied to a large degree to the ability of the extension worker to be wellversed and competent since the whole extension process is dependent on them to make available new ideas and technical advice to rural farmers.

In Malaysia, early on, one main function of the office was to implement government horticultural protocols. Under the office's supervision, establishments were authorized to implement the advancement and protection of area rights. In 1974, when the Malaysia Federal Agreement was concluded between state governments, arrangements were made for the establishment of the state bureau of agribusiness in each state. These state bureaus were given the task of carrying out improvement programs to small farmers. After the advent of entities like the Federal Agriculture Marketing Agency (1965), the Malaysia Agriculture Research and Development Institute (MARDI) (1970), and Agriculture Development Board (1973), the Department of Agriculture (DOA) was rebuilt to new capabilities (Idris, Hamzah et al. 2010).

The provision of new rural growth to farmers has been one of the central tasks of the office. MARDI was created to give innovative impetus to the agricultural progress of the nation, yet its part has further been refashioned in line with national and international advancements. In developing nations, including Malaysia, development has hinged upon the creation of a qualified labor force as well as the expansion of a specialized knowledge base (Ismail and Alexander 2005).

Within the discipline of agricultural extension, leadership has crucial longterm significane since it is concerned with mentoring farmers in rural communities. It improves their knowledge by means of communication in order to achieve predetermined and clear objectives(Khalil 2008).

\subsection{Problem Statement and Objective of study}

The leaders are a vital link connecting extension workers and farmers. They distribute educational information and try to change the farmers' mindsets. Leaders need to have a good understanding of the work of extension agents, and to be 
fully informed of the mission of extension education.Rogers (1999) points to the fact that local leaders are the people who are able in an informal manner to influence the behavior and attitudes of others towards what is desirable, and that rural leadership plays an important role in the agricultural extension program.

Nevertheless, rural leaders in granary areas are running into a few challenges. One such problem is in the implementation of new technologies. They are lacking in technical abilities due to the absence of training made available by agencies to leaders and the absence of expertise. Consequently, they often fail to transfer what they learn about new technologies to other farmers because of poor communication between the leaders and farmers.

The objective of this paper is to look at the role of rural leaders in Malaysian paddy farming and in the transfer of modern technology to farmers, and what effect new knowledge has on paddy farming in malaysia.

\section{Methodology}

The study was conducted in MADA (In state of Kedah and Perlis). The choice of the states for this research was due to the fact that the state of MADA (In state of Kedah and Perlis) has the largest paddy farming area among other state in Malaysia and also was due to the fact that major granary area in Malaysia. This study used purposive sampling technique. This research also was done by interview approaches to gain the Knowledge and Implementation Perception Levels of Rural Leaders of paddy farming technologies in MADA. The data were reviewed and revised by the researchers to determine all questions were answered by following the instructions or conditions before further analysis is done.

\subsection{Definition of Leader and Leadership}

Extension services possess unique advantages and failings, varied techniques and approaches, and set prioritized goals. Unique situations demand similarly original solutions, management styles, or systems. Often times, a solitary pioneer must master numerous aptitudes or styles to be successful. Still, no individual mentor can possess all the necessary knowledge, skills, or vantage points to lead well. Broadly speaking, one can't successfully set up the concept of initiative in an institutional setting. Therefore, leadership is indespensible for executing improvement plans. It is described by seven characteristics: Lags(Dutta and Mia 2011).

Leadership manifests itself mainly within groups. In any such group there is a chain of action and reaction between individuals. The varying degrees of power and influence within the group decides leadership. "According to Tend (1998), leadership is the activity of influencing people to cooperate towards some goal which they come to find desirable"(Reid and Karambayya 2009).

There are countless definitions of leadership depending on the specific context. Leadership is understood as a process, with this understanding in mind one could claim that leadership has to do with impact, and in order to impact a guide must have devotees and the methodology of impacting happens in a chain leading to different objectives (Bushra, Usman et al. 2011).A leader is one who exerts influence over followers. This action guides the tasks carried out by others. In the past leadership has been defined as a talent or characteristic innate to an individual. Still, despite the prevalence of this loose definition, the extent and meaning of the thought remains in need of clarification (Pfeffer 1977).

\subsection{Definition of Agricultural Extension}

The goal of agricultural extension is to promote interaction and foster synergies within a complete information system pertaining to agricultural research, agricultural education and a huge array of information-providing firms by strengthening the producers' ability to implement individual and collective action plans (Anderson and Feder 2004).

The extension doesn't just function as a link but rather enhances the efficacy of both the farmer and the research, to promote the transfer of agricultural technologies among the farmers(Rivera 1997).

Extension begins with information management and culminates with individual enrichment. Agricultural extension is by essence a crucial promoter of the enactment of novel technologies and innovations (Rogers 2010).

It brings about changes through education and communication in farmers' attitudes, knowledge and skills, and helps farmers make informed decisions (Ali, Altarawneh et al. 2012).

There are several understandings, vantage points, and strategies to agricultural extension, and the opinions of what extension is all about are in constant flux. Agricultural extension has been defined as the implementation of scientific research and new discoveries to agricultural methods through farmer education. The discipline of extension currently covers a vast range of communication and learning activities sorted through an inter-disciplinary approach. Agricultural extension connotes different meanings to different people (Purcell and Anderson 1997). 


\subsection{Agriculture and Paddy Farming Technologies}

Agricultural technology has a vital funtion in aiding the expansion of agriculture and the agro-based industry. The Malayasian government's policy, which strives to decrease reliance on unskilled foreign workers, exhorts the agriculture and agro-based industry to introduce capital and management-intensive agricultural engineering or mechanization technologies.Truong (2008) shows that there are some technologies that help both farmers and the industry. Technologies such as Integrated Pest Management (IPM), "three reductions-three gains", row seeding, harvesting by machine and rice dryers have been shown to improve paddy yields. IPM approach has some benefits like input cost reduction (savings arising from reduced seed and pesticide use) and environmental protection. That said, row seeding technology affords benefits relating to saving seeds, facilitating the processing of crops, and providing pest control; the technology also enjoys ease of implementation. Furthermore, "three reductions-three gains" stands for reducing seed rate, fertilizer and pesticide utilization in rice production to improve yields, rice quality and savings. Furthermore, rice dryers are a technological innovation that is being used by rice farmers to minimize grain loss from sun drying and the amount of hired labor required post-harvest (Abdullah and Samah 2013).

In addition, agricultural technology is very important for farmers as it first and foremost provides information and support that enhances their ability to act. Secondly, it helps agents in a similar fashion. With the right technology, both farmers and extension agents can perform better and decrease work-related dangers.Successful information technology schemes in sensitive settings have a number several key features in common. First, they are seldom only demonstations of new technology but often answers to an urgent communal challenge. Second, they are often focused on improving the availability of services to recepients instead of providing ownership. Third, they are run so as to guarantee the provision of services to all beneficiaries within a community(Pathmashini, Arulnandhy et al. 2008).

\subsection{Leaders and Leadership in Rural Development}

All organized entitites worldwide have a leader forever striving to push for the extra mile while concurrently spearheading charitable causes. Such pioneers possess a strong sense of initiative, vast energy, and a deep desire to effect significant and longlasting improvements. They similarly occupy a crucial position in the higher echelons of our political, financial, and social fabric(Williams and Lindsey 2011).Although, specific characteristics make certain individuals "amazing" guides, "Great man" hypotheses, according to which people are conceived with these attributes, plainly separated mentors from followers (Jaskyte and Dressler 2005).

A basic definition of what makes a leader is almost impossible because different leaders have different qualities and dificiencies, different philosophies and tastes, and different goals in mind. Various situations also call for different leaders, forms of leadership, or strategies. Oftentimes, a single leader must have many skills or qualities in order to prevail. At other times, no single leader can possess all the necessary knowledge, skills, or perspectives to effectively lead. Over all, one cannot easily define the notion of leadership in a set fashion. There are no agreed upon parameters of defining leadership that encompass all forms of organizations or situations and the vast literature on leadership is ample proof (Peters, Baum et al. 2007).

Thus, leadership is a way of carrying out rural development initiatives. It encompasses seven key features: LAGs .(Dutta and Mia 2011) Integrated and multisectoral actions

1) Innovation

2) Cooperation

3) Networking

4) Area-based local development strategies

5) Bottom-up elaboration and implementation of strategies

6) Local public-private partnerships

In the past, psychologists have defined leadership as a specific quality of character, talent, or skill that is innate to an individual. Still, despite this broad definition, leadership continues to be a strong area of development and research, and the scope and understanding of the concept remain unclear (Zaccaro 2001).

Broadly speaking, leadership can be understood through the paradigm in question and by which the leader's actions are governed. Leadership is seen by some as the subtle art of swaying people (Russell 2001).

It goes without saying that the difficulties encountered by rural leaders and their communities are becoming more complicated and at the mercy of external political, social, cultural, and economic forces, be they local or global in origin. These difficulties have forced rural leaders to deepen their awareness of the root causes of the challenges at hand, the 
possible scenarios and available alternatives, and the different routes leading to the desired end. Though most of the techinques and traits they boast are the product of their lifestyle and environment, some are clearly the fruit of both theoretical and hands-on leadership training programs (Williams and Lindsey 2011).

Keating (2011) concluded that participants in community leadership training had a greater rate of overall community organization membership compared to non-participants. Furthermore, Jennings (2009) reported that the trainees gained a level of confidence and competency that motivated them to look for other leadership opportunities at the conclusion of the program, and that $66 \%$ said attaining additional knowledge and skills improved their efficiency (Reierson, Hvidsten et al. 2013).

Thus, leadership is a goal-oriented endeavour with self-contained values. Insofar that leadership as a concept is preoccupied with reform, the leader is in essence an agent for progress. Leadership doesn't have to be tied to official titles or positions; anyone can become a leader(Jean-Marie, Normore et al. 2009).

In our ever-changing environment, leaders have to constantly reinvent themselves to deal with unstable circumstances in order to meet countless challenges, while simultaneously exercising financial discipline. Despite the numerous references suggesting a link between leadership and financial considerations in several reports, futher research is needed to shed more light on the significance of any such link to agricultural leaders. Such is the importance of these ideas to the creation of organizations that more investigation is urgently needed to avail leaders of relevant new findings (Jackson and Parry 2011).

Malaysia is often held up as a pioneering nation, among developing economies, in executing rural development initiatives. Rural reform began in 1957, with Pre-new Economic Policy to alleviate the hardship of impoverished populations. During the Second Transformation of Rural Development phase (1994 - 2000), the aim was to narrow the gap in economic growth between rural and urban parts, in harmony with the Malaysian Vision Policy that would bring about a more egalitarian society (Jean-Marie, Normore et al. 2009).

\subsection{Knowledge}

Both internal and external expertise are crucial factors in enhancing small-scale agricultural ventures and delivering their produce to lucrative markets, thereby boosting rural incomes, elevating quality and yield, food security and national revenue (Asaba et al., 2006). In the absence of proper guidance, contract farmers cannot carry out sound agricultural practices (Azman, D'Silva et al. 2012).

There are certain indespensible strategies that need to be adopted for greater creativity within the field of agricultural extension, including:

1) Research and development focused on farmers: - There is ample evidence that investment in horticultural R\&D gives great dividends. It follows then that governments should support participatory horticultural examination to assist agriculturists in deepening their knowledge which should in turn reduce persistent poverty problems. Plans should be put in place to induce private capital to back farming research. Planners can also steer agricultural firms towards greater investment in food research. Properly targeted financial support for innovative work would result in faster positive results. Structural enhancements in examination associations could include an emphasis on participatory examination that would promote the nutrition and farming value chain(Asenso-Okyere and Davis 2009).

2) Agricultural extension: - Horticultural amplification is a central component with the potential to bring together examiners, agriculturists, and others within the development scheme. Amplification is the sum of measures that support agricultural advisors in overcoming the challenges involved with technical knowledge acquistion thereby ameliorating their performance and rewards. Development strategies have improved at the local and national levels, in preparation and inspection, with greater shift towards privatization. The focus is less concerned with technique and is more result oriented in order to provide tailored and unique solutions. Approaches that ignore client needs often fade quickly. A lot of farmers complain about the inadequacy of expansion administrations which are often viewed as supply-driven, too uniform, and top-down frameworks that exclude the poor. For example, women agriculturists receive just $5 \%$ of expansion administrations globaly, although research has shown that profits increase by $22 \%$ when women get the same consultative administrations as men (Nabi, Liñán et al. 2011).

3) Education and capacity enhancement: - Limit reinforcing is an indespensible tool for furthering education and progress. Participants, both in the field and at planning levels, are in need of more assistance so that they can function better. Farmers and farming groups acknowledge that it is in their interest to receive such support, 
and know how it impacts growth positively and makes it easier to get further growth administrations. Entities which despense amplification administrations, whether open or private segment, or common social order, must demonstrate timely sensitivity to client needs. Moreover, scientists have to improve their working relationship with farmers and their quality of communication with augmentation workers. Furthermore, planners must improve their awareness of the enhancement scheme in greater detail (Hamilton 1996).

\subsection{Implementation}

Implementation is the recognition and active participation in the removal of obstacles in order to exploit newly available findings (Lomas 1993).

Implementation is the putting into action, actualization, or adoption of a strategy, a technique, or any scheme for pursuing a goal. Thus defined, implementation is the necessary meaure coming after all initial analysis in order to realize goals. Within an information technology framework, implementation includes all the steps necessary for new software or hardware to function properly in its setting, including installation,configuration running, testing, and troubleshooting. The term deployment is sometimes used interchangeably(Heracleous and Barrett 2001).

\section{Conclusion}

This paper opened with a short overview of fundamental leadership concepts which showed that effective leadership in an organization is vital. Rural leadership is of paramount importance, particularly in the field of agricultural extension, because of its central role in the provision of education and training opportunities for farmers thereby enhancing their skills and capabilities in all fields of agricultur.

\section{References}

Abdullah, F. A. and B. A. Samah (2013). "Factors impinging farmers' use of agriculture technology." Asian Social Science 9(3): p120.

Alam, M. M., C. Siwar, M. W. Murad, R. I. Molla and M. E. b. Toriman (2010). "Socioeconomic profile of farmer in Malaysia: study on integrated agricultural development area in North-West Selangor." Agricultural Economics and Rural Development 7(2): 249-226.

Ali, A.-S., M. Altarawneh and E. Altahat (2012). "Effectiveness of agricultural extension activities." American Journal of Agricultural and Biological Sciences 7(2): 194-200.

Anderson, J. R. and G. Feder (2004). "Agricultural extension: Good intentions and hard realities." The World Bank Research Observer 19(1): 41-60.

Asenso-Okyere, K. and K. Davis (2009). Knowledge and innovation for agricultural development, International food policy research institute (IFPRI).

Austin, O. C. and A. H. Baharuddin (2012). "Risk in Malaysian agriculture: The need for a strategic approach and a policy refocus." Kajian Malaysia 30(1): 21-50.

Azman, A., J. L. D'Silva, B. A. Samah, N. Man and H. A. M. Shaffril (2012). "Comparative study on sustainable agriculture knowledge among Malaysian contract farmers." American Journal of Applied Sciences 9(5): 673.

Bushra, F., A. Usman and A. Naveed (2011). "Effect of transformational leadership on employees' job satisfaction and organizational commitment in banking sector of Lahore (Pakistan)." International journal of Business and Social science 2(18): 261-267.

Dorward, A., N. D. Poole, J. Morrison, J. Kydd and I. Urey (2003). "Markets, institutions and technology: missing links in livelihoods analysis." Development policy review 21: 319-332.

Dutta, S. and I. Mia (2011). The global information technology report 2010-2011. World Economic Forum.

Firdaus, R. R., I. A. Latiff and P. Borkotoky (2012). "The impact of climate change towards Malaysian paddy farmers." Journal of Development and Agricultural Economics 5(2): 57-66.

Hamilton, N. D. (1996). "Tending the seeds: The emergence of a new agriculture in the United States." Drake J. Agric. L. 1: 7.

Hassan, M. S., H. A. Shaffril, B. A. Samah, M. S. Ali and N. S. Ramli (2010). "Agriculture communication in Malaysia: The current situation." American Journal of Agricultural and Biological Science.

Heracleous, L. and M. Barrett (2001). "Organizational change as discourse: Communicative actions and deep structures in the context of information technology implementation." Academy of Management Journal 44(4): 755-778.

Idris, K., A. Hamzah and J. Uli (2010). "Competencies influencing extension workers job performance in relation to the good agricultural practices in Malaysia." American Journal of Applied Sciences 7(10): 1379-1386.

Ismail, H. N. and J. M. Alexander (2005). "Learning within scripted and nonscripted peer-tutoring sessions: The Malaysian context." The Journal of Educational Research 99(2): 67-77.

Jackson, B. and K. Parry (2011). A very short fairly interesting and reasonably cheap book about studying leadership, Sage.

Jadalla, A., A. H. A. Bakar, H. M. Jais and F. M. Shalloof (2013). "The impact of major constraints on agricultural extension in eastern Libya." Journal of Agricultural Technology 9(2): 257-269. 
Jaskyte, K. and W. W. Dressler (2005). "Organizational culture and innovation in nonprofit human service organizations." Administration in social work 29(2): 23-41.

Jean-Marie, G., A. H. Normore and J. S. Brooks (2009). "Leadership for social justice: Preparing 21st century school leaders for a new social order." Journal of Research on Leadership Education 4(1): 1-31.

Khalil, A. H. O. (2008). Relationships Between Extension Competencies, Organisational Commitment And Job Satisfaction With Performance Of Agricultural Extension Workers In Yemen, Universiti Putra Malaysia.

Lomas, J. (1993). "Diffusion, dissemination, and implementation: who should do what?" Annals of the New York Academy of Sciences 703(1): 226-237.

Man, N. (2009). "Factors affecting the decision making in off farm employment among paddy farmers in Kemasin Semerak." Pertanika Journal of Social Sciences \& Humanities 17(1): 7-15.

Nabi, G., F. Liñán, J. Mitra, Y. Abubakar and M. Sagagi (2011). "Knowledge creation and human capital for development: the role of graduate entrepreneurship." Education+ Training 53(5): 462-479.

Nagel, U. (1997). "Improving agricultural extension: a reference manual." Rome: Italy, FAO.

Pathmashini, L., V. Arulnandhy and R. W. Wijeratnam (2008). "Cultivation of oyster mushroom (Pleurotus ostreatus) on sawdust." Ceylon J Sci Bio Sci 37: 177-182.

Peters, L., J. Baum, K. Hannum, J. Martineau and C. Reinelt (2007). "The importance of local context in leadership development and evaluation." The handbook of leadership development evaluation: 261-283.

Pfeffer, J. (1977). "The ambiguity of leadership." Academy of management review 2(1): 104-112.

Purcell, D. and J. R. Anderson (1997). Agricultural extension and research: Achievements and problems in national systems, World Bank Publications.

Reid, W. and R. Karambayya (2009). "Impact of dual executive leadership dynamics in creative organizations." Human relations 62(7): 1073-1112.

Reierson, I. A.., A. Hvidsten, M. Wighus, S. Brungot and I. T. Bjørk (2013). "Key issues and challenges in developing a pedagogical intervention in the simulation skills center-an action research study." Nurse education in practice 13(4): 294-300.

Rivera, W. M. (1997). "Agricultural extension into the next decade." European Journal of agricultural education and extension 4(1): 2938.

Rogers, E. M. (2010). Diffusion of innovations, Simon and Schuster.

Rosegrant, M. W., S. Msangi, C. Ringler, T. B. Sulser, T. Zhu and S. A. Cline (2008). International model for policy analysis of agricultural commodities and trade (IMPACT): model description, International Food Policy Research Institute Washington, DC, USA.

Roslan, N. A., A. M. Abdullah, M. M. Ismail and A. Radam (2012). "Determining Risk Attitudes of Paddy Farmers in KETARA Granary, Malaysia." International Journal of Social Science and Humanity 2(3): 225.

Russell, R. F. (2001). "The role of values in servant leadership." Leadership \& Organization Development Journal 22(2): 76-84.

Shaffril, H. A. M., A. Asmuni and A. Ismail (2010). "Menu." Journal of International Social Research 3: 450-458.

Williams, L. L. and M. J. Lindsey (2011). "Rural Leaders and Leadership Development in Pennsylvania." Center for Rural Pennsylvania.

Yin, S. A., A. Ismail and S. Z. Zulkifli (2012). "Copper and zinc speciation in soils from paddy cultivation areas in Kelantan, Malaysia." Acta Biologica Malaysiana 1(1): 26-35.

Zaccaro, S. J. (2001). The nature of executive leadership: A conceptual and empirical analysis of success, American Psychological Association. 
